\title{
“LA CATEDRAL Y EL RÍO”: SOBRE OCNOS, DE LUIS CERNUdA
}

\author{
Ivan Martucci Forneron
}

\section{EPÍGONO DE LUIS CERNUDA E DA GERAÇÃO DA II REPÚBLICA}

Uma das grandes qualidades da obra do poeta espanhol Luis Cernuda (1902-1963) é o alcance de interrogações que seu leitor conquista. E são interrogações que se avolumam porque mais do que a releitura, própria do gênero poético, o texto cernudiano nos encaminha - sem que tomemos isso como exigência - para um jogo, apenas para ficar num exemplo, em que imagens e vozes disputam a emissão de um discurso que, entre outros recursos, é feito por meio do deslocamento incessante do pronome "tu", que arroga para si não apenas as máscaras dos demais pronomes, gêneros e números, mas também por intercalar a fala e o silêncio tanto do que é inanimado quanto das bocas desejantes e desejadas. La realidad y e el deseo, título com o qual seu autor enfeixou toda a sua obra de poesia, representa bem, a princípio, esse conflito aporético, bem como suas escolhas formais, que se assemelham a um caleidoscópio no qual, a cada girar, vemos incorporados um repentino diálogo, um novo autor, uma confissão contraditória, uma referência intertextual ou plástica etc. A isso somemos a personalidade incomum dos que conjugam austeridade com aristocracia em meio à precariedade material, que mais tarde será alinhavada por um exílio que se torna antiodisseico, sobretudo a partir de 1947, ano em que o poeta parte de Londres para os Estados Unidos e de lá, tempos depois, para o México, onde morre em 1963. 
Tomando sua obra em conjunto, vemos a predominância de uma tríade: o incessante diálogo entre a História e a sua história, o poder ambíguo, de criar e destruir, que a cultura humana possui e exerce com o mesmo vigor e, por fim, a beleza do corpo jovem masculino. Essas três estruturas leem, decifram e interpretam o tempo, a memória e a experiência de Luis Cernuda.

É evidente que essas observações são apenas uma porta de entrada para a obra de um poeta, cujo trabalho se estendeu pela crítica e pela tradução com a mesma qualidade e disciplina. É preciso considerar, ainda, o prolífico missivista que nos legou um testemunho precioso para enriquecer e confrontar a historiografia literária espanhola, aportando dados biográficos, práticas editoriais, o cotidiano de um indivíduo e de sua geração entre duas guerras e o pulsar do espírito humano no transcorrer desse tempo, marcado por experiências e transformações que ressoam até os nossos dias.

Luis Cernuda é um dos poetas mais influentes da literatura espanhola do século XX, e a leitura dos seus textos muito nos revela e ensina, por isso sua obra é incontornável para compreendermos as grandes lacunas que a historiografia espanhola infelizmente ainda possui, principalmente quando agrupa esse poeta sevilhano e seus contemporâneos sob a redutora e limitada etiqueta de "Generación del 27", dando-nos uma perspectiva evolutiva da história literária muito conveniente ao que lhe é dissonante e espinhoso. Que a Geração de 27 faz, no ano de 1927, uma homenagem pelo tricentenário da morte de Góngora e, ainda, reatualiza a leitura do poeta cordovês, isso é um fato, mas há um componente político sendo fomentado naquele momento que está além do autor de Soledades: a maioria de seus jovens leitores e também poetas são entusiastas das vanguardas e suas discussões extrapolam o campo da arte, forçando as mudanças que desembocariam na II República, a qual teria lugar pouco tempo depois, em 1931. Portanto, a designação "Generación del 27" representa apenas uma face dessa geração que estaria melhor nomeada como "Geração da II República”, pois, enquanto o marcador "del 27" remete apenas à homenagem a Góngora, a expressão "Geração da II República” invoca a Guerra Civil Espanhola, os desastres do pós-guerra civil e, o que mais toca a essa geração à qual pertence o autor de Ocnos: a perseguição, a censura e o exílio.

\section{CRONOLOGIA E NOMENCLATURAS DE OCNOS}

Como todo republicano da sua geração, Cernuda conheceu as interdições com as quais teve que lidar na construção da sua obra. No seu 
caso, mais especificamente, o que chamamos de interdições são eventos anteriores à Guerra Civil: seu pouco entusiasmo para os melindres de certos ambientes literários, uma indisfarçável e muitas vezes ríspida timidez e o homoerotismo declarado nas primeiras obras, tendo em Los placeres prohibidos (1931) seu maior exemplo. Seus livros posteriores, Donde habite el olvido (1932-1933) e Invocaciones (1934-1935), são os últimos escritos na Espanha. Posteriormente toda a sua obra é feita no exílio, a começar por Las nubes (1937-1940), escrito em Londres, durante a Guerra Civil Espanhola.

Esses dados cronológicos nos servem, num primeiro momento, para especular sobre a gestação de Ocnos, concebido entre duas catástrofes que se sucedem imediatamente uma após a outra, a Guerra Civil Espanhola e a Segunda Guerra Mundial, eventos que imprimem um sentimento de dissolução do mundo pressagiado já em Las nubes. As ruínas desse mundo entreguerras são as bases da composição de suas obras seguintes: Como quien espera el alba (1941-1944) e Vivir sin estar viviendo (1944-1949). No meio desse mundo, debaixo de bombas, está o nascimento de Ocnos, livro que possui, individualmente - pois nunca foi incorporado pelo autor a La realidad y el deseo -, três edições: a primeira, em 1942, pela Editorial The Dolphim Press, Londres; a segunda, em 1949, pela revista Ínsula, de Madrid; e a terceira e última edição, em 1963, que Cernuda não chegou a ver publicada, saiu pela Universidad Veracruzana, de Xalapa, México. A edição que utilizamos para o presente artigo é Poesía completa de Luis Cernuda, publicada por Ediciones Siruela, Madrid, 2005, e organizada por Derek Harris e Luis Maristany.

Até onde pudemos apurar, a primeira citação a Ocnos nos é dada pelo seu autor em correspondência de 6 de abril de 1942, com Gregorio Prieto (CERNUDA, 2003, p. 316): "El libro que pienso publicar es bastante breve, y si tú no tienes inconveniente pienso engalanarlo con un dibujo

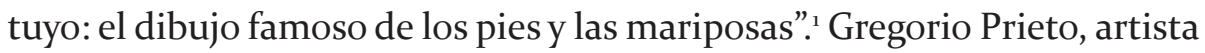
plástico e amigo estimado e querido de Cernuda, igualmente exilado, recebia o poeta por algumas temporadas em seu modesto apartamento, em Londres, principalmente no período da Segunda Guerra, e são dele alguns desenhos que tomam Cernuda como modelo, inclusive o que é mencionado na carta. Outra correspondência, também referente a Ocnos, quase no mesmo período, de 16 de abril de 1942, enviada a Nieves Mathews,

1 "O livro que pretendo publicar é bastante breve, e se você não achar inconveniente, queria ilustrá-lo com um desenho seu: o famoso desenho dos pés e das borboletas.” 
também amiga do poeta e com quem Cernuda (p. 317) se corresponde por muitos anos, amplia nossas informações sobre a obra: “Tengo el proyecto de imprimir un libro, y seguir en adelante, si me es posible, editando mis cosas. Este libro, casi poético, aunque no en verso, se llama Ocnos y lleva al frente unas líneas de Goethe que subrayan el significado del título". Ocnos se gesta, portanto, após o término da Guerra Civil Espanhola e ganha corpo no meio da Segunda Guerra Mundial. Uma vez iniciada sua escritura, será para o poeta, como veremos adiante, um lugar, uma geografia sempre em movimento e, como obra propositalmente de caráter inacabado, encontra correspondência naquele famigerado dizer roseano "onde os pastos carecem de fecho" (ROSA, 2001, p. 24).

Aqui é preciso nos deter sobre a menção que Cernuda (2003, p. 317) faz sobre "las líneas de Goethe que subrayan el significado del título". 3 O texto de Goethe a que alude Cernuda e que ele mesmo traduz na introdução de Ocnos é este:

Er flicht eben von Natur, wie sie von Natur frisst; er könnte lieber aufhören zu flechten; aber was alsdann sonst beginnen? Er flicht lieber um zu flechten, und das Schilf, das sich anch ungeflochten hätte verzehren lassen, wird nun geflochten gespeist. Vielleicht schrneckt es so, vielleicht nährt es besser? Dieser Oknos, könnte man sagen, hat auf diese Weise doch eine Art von Unterhaltung mit seiner Eselin!

GOETHE. Polygnots Gemälde in der Lesche zu Delphi. ${ }^{4}$

Luis Cernuda nãoé oúnico escritor espanhol influenciado pela cultura alemã. A geração que lhe antecede e a sua própria têm na sua formação, direta ou indiretamente, grande familiaridade com autores como Hölderlin, Goethe e Heine. Artistas, intelectuais, políticos e poetas como Emilio Prados, Max Aub, Sanz del Río, Manuel Azaña, Francisco Giner de los Ríos, entre tantos outros, estão imbuídos de boa parte da cultura

\footnotetext{
2 "Tenho um projeto de mandar imprimir um livro e seguir adiante, se me for possível, editando minhas coisas. Esse livro, quase poético, ainda que não seja em verso, chama-se Ocnos, e no começo tem uma citação de Goethe, que ressalta o significado do título."

3 "[...] as linhas de Goethe que ressaltam o significado do livro."

4 "Para Ocnos era tão natural trançar os juncos como o era para o asno comê-los. Podia deixar de trançá-los, mas, então, iria se dedicar a quê? Prefere, por isso, trançar os juncos, para estar ocupado; se o asno come os juncos trançados, os comeria da mesma forma se assim não estivessem. Inclusive, pode ser que trançados tenham melhor sabor, ou sejam mais substanciosos. E se poderia dizer, até certo ponto que, desse modo, Ocnos encontra no seu asno uma forma de passatempo./ GOETHE. As pinturas de Polignoto nas ânforas de Delfos."
} 
humanista e/ou romântica alemã, quer como fundadores ou alunos da Institución Libre de Enseñanza (ILE), um dos raros locais de ensino laico na Espanha daqueles tempos e cuja base político-pedagógica é orientanda pelo ideal humanista de Karl Christian Friedrich Krause (1781-1832), quer pela iniciativa dos poetas espanhóis ao traduzirem os poetas românticos alemães, tal como o faz Cernuda com Hölderlin.

A menção a Goethe, no entanto, como origem para o título que Cernuda dá à obra, como bem podemos ler no texto em alemão que ele próprio traduz, invoca o que se pode chamar de "questões sobre questões" e que estão trançadas numa tradição cultural que nos exige um olhar atento para agrupá-las, no mínimo, em três ângulos: uma certa tradição aqui entendida como a formação do poeta; o momento histórico-político de composição da obra; e, por fim, o próprio fazer literário e/ou criação artística. A tradição mencionada recupera noções e saberes submetidos ao tempo que os constrói, dilata, fragmenta, desconstrói e os recupera por diversos meios que o registro, o uso e o cuidado e/ou a omissão de cada tempo e lugar possuem.

O termo "Ocnos" com que Goethe nomeia um camponês é, dentro da obra, além de um nome próprio, um verbo, um adjetivo e um advérbio. Sua relação com o burro/asno, animal de grande valor como aliado do homem na execução das tarefas árduas de subsistência, perde-se em incontáveis tradições orais de contos e lendas, sempre, ao contrário do que se lhe atribui modernamente, como um ser astuto, ou como presente que se ganha, por mérito ou por bênção divina, para uma boa e segura travessia, para um bom viver. Um dos exemplos clássicos é $O$ asno de ouro, de Apuleio, que nos remete à inesgotável relação viagem/aprendizagem e ao relato dessa relação, que também é um dos pontos cruciais na obra de Luis Cernuda, como exilado e tendo nas sucessivas viagens, voluntárias e involuntárias, a própria ideia de transformação e transcendência. Sobre essas duas últimas expressões, e ainda sobre Apuleio (1985), convém citar parte da breve introdução da tradutora, Ruth Guimarães, à versão latina do texto:

$\mathrm{O}$ autor do livro que se chamou Metamorfoses, $O$ asno, $O$ asno de ouro, ou Lúcio, nos aparece envolto em mistério. O próprio livro, que tem tantos vocativos, mal se sabe como foi primitivamente batizado. Parece provado que o nome pelo qual é mais conhecido modernamente - $O$ asno de ouro - veio de uma aposição do restritivo "de ouro" ao nome primeiro de "Asno", porque se tratava de uma história de ouro para ser lida, de ouro para ser apreciada, de 
"La catedral y el río": sobre Ocnos, de Luis Cernuda - 726

ouro porque de ouro mesmo, tão extraordinária era; e o restritivo implica um julgamento.

Essa história de ouro, por assim dizer, pode resumir, num primeiro momento, o que chamamos de tradição/formação de Luis Cernuda, inserido nessa narrativa humana da qual ele toma conhecimento e da qual se serve como forma para incorporar-se a ela, como é o caso da narrativa em estudo, pelo fazer literário, tendo como assunto - e aqui entramos no segundo ângulo de observação - seu tempo histórico-político, não porque Ocnos também trate da Guerra Civil, da Segunda Guerra e do exílio, mas porque é um olhar que mostra como alguém, dadas as condições que lhe coube viver, respondeu ao seu tempo histórico-político - o que desemboca na leitura do terceiro ângulo: a criação e o fazer literário. É nesse ponto, tal qual os trançados de Ocnos, que formação, momento histórico e criação literária de Cernuda e de sua obra enfeixam-se.

Numa outra referência a Goethe, Palabras antes de uma lectura (1935) (CERNUDA, 2003, pp. 602-605), em meio a um texto que trata do instinto e expressão poéticos, podemos ver como se conjugam os elementos que vimos tratando. Sua leitura é muito valiosa como marco do pensamento estético do autor de La realidad y el deseo:

El instinto poético se despertó en mí gracias a la percepción más aguda de la realidad, experimentando, con un eco más hondo, la hermosura y la atracción del mundo circundante. Su efecto era, como en cierto modo ocurre en el deseo que provoca el amor, la exigencia, dolorosa a fuerza de intensidad, de salir de mí mismo, anegándome en aquel vasto cuerpo de la creación. Y lo que hacía aún más agónico aquel deseo era el reconocimiento tácito de su imposible satisfacción. [...] la realidad exterior es un espejismo y lo único cierto mi propio deseo de poseerla. Así pues, la esencia del problema poético, a mi entender, la constituye el conflicto entre realidad y deseo, entre apariencia y verdad, permitiéndonos alcanzar alguna vislumbre de la imagen completa del mundo que ignoramos, de la "idea divina del mundo que yace al fondo de la apariencia”, según la frase de Fichte. [...] ¿Qué puede el poeta por sí? Nunca como ahora la sociedad ha reducido la vida a tan estrechos límites. Y ciertamente el poeta es casi un revolucionario, yo por lo menos así lo creo; un revolucionario que como los otros hombres de libertad, pero a diferencia de éstos no puede aceptar esa privación y choca innumerables veces contra los muros de su prisión. La mayoría de las gentes produce hoy la impresión de cuerpos amputados, de troncos podados cruelmente. Como a casi todo puede dársele doble interpretación, alguno recordará ahí que limitarse es necesario, y supone madurez. No soy de los últimos a reconocer el valor de la limitación, o de la resignación, para dar a esa virtud su verdadero nombre cristiano. Mas esto no es obstáculo para que al contemplar la vida me parezca asistir a una desagradable comedia policíaca, y si otras sociedades estimaron al artista o al filósofo, esta de hoy adora al polizonte. Reconozco por tanto 
que para mí las posibilidades materiales inmediatas de la actividad poética parecen negativas. [...] La sociedad moderna, a diferencia de aquellas que la precedieron, ha decidido prescindir del elemento misterioso inseparable de la vida. No pudiendo sondearlo, prefiere aparentar que no cree en su existencia. Pero el poeta no puede proceder así, y debe contar en la vida con esa zona de sombra y de niebla que flota en torno de los cuerpos humanos. Ella constituye el refugio de un poder indefinido y vasto que maneja nuestros destinos. Alguna vez he percibido en la vida la influencia de un poder demoníaco, o mejor dicho, daimónico, que actúa sobre los hombres. [...] Leyendo un estudio de cierto arabista acerca de la vida y doctrina de un teólogo musulmán, hallé esta respuesta del teólogo en cuestión a uno de sus discípulos; mientras caminaban por la calle, uno de aquéllos le preguntó al oír un son de flauta: "Maestro, ¿qué es eso?” Y el maestro le respondió: “Es la voz de Satán que llora sobre el mundo". Según aquel teólogo, Satán ha sido condenado a enamorarse de las cosas que pasan, y por eso llora; llora, como el poeta, la pérdida y la destrucción de la hermosura. [...] Pero ese llanto no excluye que de la contemplación de la hermosura, aunque efímera, nazca en el poeta una alegría terrible, porque los sentimientos rara vez dejan de presentarse mezclados con sus contrarios en nuestra vida: sólo en la unión de los extremos podemos intuir una armonía superior a los poderes de la comprensión humana. [...] A ese poder daimónico alude Goethe en sus conversaciones con Eckermann, y acaso sea el mismo que consumía la vida de Hölderlin, tal el fuego de la zarza ardiente que vió Moisés. Confundido con el don lírico que habitó en ciertos poetas, parece como si las fuerzas físicas de éstos no pudieron resistirle, viéndose, arrastrados a la destrucción, para alcanzar, al fin, tras la muerte, una enigmática libertad. ${ }^{5}$

5 "O instinto poético foi despertado em mim graças à percepção aguda da realidade, ao experimentar, como um eco mais fundo, a beleza e a atração do mundo circundante. Seu efeito foi, como de certa forma acontece no desejo que provoca o amor, a exigência, doída pela sua intensidade, de sair de mim mesmo, inundando-me naquele vasto corpo da criação. E o que fazia mais agônico ainda aquele desejo era o reconhecimento tácito de sua impossível satisfação. [...] a realidade exterior é uma miragem que meu desejo quer possuir. Desse modo, a essência do problema poético, no meu entender, é constituída pelo conflito entre realidade e desejo, entre aparência e verdade, o que nos permite alcançar algum vislumbre da imagem completa do mundo que ignoramos, da 'ideia divina do mundo que está ao fundo da aparência', segundo a frase de Fichte. [...] O que pode um poeta? Nunca como hoje a sociedade reduziu a vida a limites tão estreitos. E certamente o poeta é quase um revolucionário, pelo menos eu assim o entendo; um revolucionário como todos os outros homens inclinados à liberdade, mas, ao contrário destes, não aceita a privação e se debate inumeráveis vezes ente os muros de sua prisão. A maioria das pessoas, hoje, dá a impressão de corpos amputados, de troncos podados cruelmente. E como a quase tudo podemos conferir dupla interpretação, quiçá alguém por aí pode nos lembrar que se limitar é necessário, supondo-se, com isso, maturidade. Não sou o último a reconhecer o valor da limitação, ou da resignação, para dar a essa virtude o seu verdadeiro nome cristão. Mas isso não é obstáculo para que o contemplar da vida seja reduzido a uma desagradável comédia policial. Se outras sociedades estimaram o artista e o filósofo, a nossa de agora adora o policialesco. Reconheço, portanto, que para mim as possibilidades materiais imediatas da atividade poética parecem negativas. [...] A sociedade moderna, diferentemente daquelas que a precederam, decidiu prescindir do elemento misterioso inseparável da vida. Não 
É um texto valioso, como já dissemos, porque mostra o caminho pelo qual Luis Cernuda aprofundará sua ética-estética, bem como sua criação literária ao longo da vida em pátrias moventes - França, Reino Unido, Estados Unidos e México -, lares adotados e adotivos, e também porque nos dá, de antemão, elementos para tratar de Ocnos a partir de um intraduzível e inexplicável daimon. Note-se, ainda, nesse texto, que é de 1935, uma percepção aguda que antevê, por meio da imagem de corpos amputados, uma nação que um ano depois mergulhará na catástrofe de uma guerra mundial.

Esses elementos, portanto, de tradição, leitura da história e criação estão profundamente entrelaçados numa simples menção ao texto de Goethe, que está, também a seu tempo, pensando sobre Polignoto. Ou seja, um espanhol que retoma um alemão, que retoma um grego que trata de um templo, mais precisamente o de Delfos, com toda a carga helênica e socrático-platônica que isso representa. São testemunhos sobre testemunhos, experiências sobre experiências. Os trançados de Ocnos, ainda que destinados ao nada, ao inútil ou ao esquecimento, mostram o pouco ou nenhum valor da finalidade. São trançados que se revelam/ significam, tal qual o oráculo, pela metáfora da junção, do diálogo, da experiência e do testemunho.

Ocnos também poderia ser grafado como oknus, como verbo, ou como o mito do procrastinador. Tem o sentido e o símbolo de um oximoro: o pensamento, ao questionar-se sobre o porquê do fazer inútil, é o mesmo

podendo sondá-lo, prefere aparentar que não acredita na sua existência. Mas o poeta não pode fazer o mesmo e deve contar com essa zona de sombra e névoa da vida, que flutua ao redor dos corpos humanos. Ela constitui o refúgio de um poder indefinido e vasto que dirige nossos destinos. Já percebi a influência de um poder demoníaco sobre a vida, melhor dizendo, daimônico, que atua sobre os homens. [...] lendo o estudo de um certo arabista sobre a vida e a doutrina de um teólogo muçulmano, encontrei esta resposta do teólogo em questão a um de seus discípulos; enquanto caminham pela rua, ao ouvir um som de flauta, o discípulo pergunta: 'Mestre, o que é isso?' E o mestre lhe respondeu: 'É a voz de Satã chorando sobre o mundo'. Segundo o teólogo, Satã foi condenado a se apaixonar pelas coisas que passam, e por isso chora; chora como o poeta a perda e a destruição da beleza. [...] Mas esse choro não impede que da contemplação da beleza, ainda que efêmera, nasça no poeta uma alegria terrível, porque os sentimentos raramente se mostram misturados com os seus contrários em nossas vidas: apenas na união dos extremos podemos intuir uma harmonia superior aos poderes da compreensão humana. [...] A esse poder daimônico alude Goethe em suas conversações com Eckermann, e é possível que seja o mesmo que consumia a vida de Hölderlin, como o fogo da sarça ardente que viu Moisés. Confundido com o dom lírico que habitou certos poetas, foi como se suas forças físicas não pudessem ter resistido a esse fogo, e foram arrastados para a destruição, alcançando no fim, com a morte, uma enigmática liberdade." 
que o nega se perguntando por que não fazer. E, como o pensamento contraditório - que afirma e nega e torna a afirmar - é o processo mesmo do conhecimento e como são perguntas que não se respondem, ou que se respondem umas sobre às outras em pedaços que nos auxiliam na travessia, não há problema em que seu aspecto formal seja de fragmentos e pedaços, que não se destinam a um fim - palavra aqui entendida tanto como finalidade como ponto final: a antítese do inacabado. Por isso, em vários momentos de sua correspondência, Cernuda refere-se a Ocnos de diversas maneiras: como prosa poética, como textos breves, como "trozos" [pedaços], evidenciando uma dificuldade confessada em classificá-lo; também como a figura do camponês Ocnos, entendida como questão que não merece mais atenção do que o próprio fazer, sendo esse fazer o verbo ordinário do cotidiano, a ação de fazer qualquer coisa; e por fim pensando no verbo grego "poio", que significa igualmente fazer, e que designa "poesis", criação, num sentido mais amplo mesmo, como a criação literária e artística.

Como podemos ver, o título de Ocnos e sua estrutura formal nos permitem uma possibilidade ampla de investigação e interrogações que não se esgotam. É preciso considerar que é uma obra escrita ao longo de mais de vinte anos (1942-1963). Nela coube o que em nenhuma outra obra o poeta entendeu que caberia. Também não é memória nem crônica, ainda que incorpore os elementos delas. Para termos noção da complexidade da obra, pensando nas tentativas da fortuna crítica em classificá-la, convém citar uma nota elucidativa que acompanhou a terceira versão de Ocnos (CERNUDA, 2003, p. 661):

\footnotetext{
A [esta tercera edición] le hubiera gustado [al autor] añadir, separados, pero bajo la misma cubierta, los poemas en prosa que constituyen el librito Variaciones sobre tema mexicano, análogos quizá en género y en expresión a los de Ocnos; pero la edición de Variaciones, comprada por editor distinto, permanece ahora soterrada en sótano editorial, donde nadie sabe que existe, y comprarla, para tener derecho a unirse a la edición presente, era cosa no hacedora de momento a su autor. ${ }^{6}$
}

\footnotetext{
6 "Para esta [terceira edição], eu teria preferido acrescentar, separados, mas com a mesma capa, os poemas que constituem o livrinho Variações sobre um tema mexicano, parecidos talvez, em expressão e gênero, aos de Ocnos; mas a edição de Variações, comprada por um editor diferente, deve estar agora soterrada em algum canto inóspito, onde ninguém sabe que existe, e comprar seus direitos para a presente edição é algo que não posso fazer agora.”
} 
Embora cite a expressão gênero, ele não especifica de qual gênero se trata, nem para Ocnos nem para Variaciones sobre tema mexicano, levando-nos a considerar outras e infindas interrogações, entre elas, a do caráter especular e extensivo entre essas duas obras, como seu nascimento e morte, como uma única terra em movimento. Há, por fim, um trato que lhes dá o autor e que vemos mencionado também em carta a Nieves Mathews (CERNUDA, 2002, pp. 331-333), referindo-se a Ocnos como o regate de uma vida e também como um poço de silêncio, discorrendo, ainda, sobre o ofício do poeta, do filósofo e as fronteiras e limites da criação:

Siento que no hayas visto Ocnos; no está mal, pero han deslizado en la tirada erratas que no había en las pruebas, aunque son erratas visibles y que no alteran el texto, sino su ortografía. Para mí es casi un alivio ver esas páginas publicadas; son o pretenden ser, un rescate de mi vida, de la vida en general. Como es natural, espero que el libro caiga en un pozo de silencio, y sin paradoja espero al mismo tiempo que el libro dure más que yo. [...] Tu comentario sobre el libro ya puedes suponer cuánto me complace. No me extraña eso de que su lectura te retrae al mundo de tu niñez: en temperamentos equivalentes, como los nuestros, es cosa natural que, aun siendo el medio distinto, la reacción sea parecida. Lo que yo no haría tan extensivo es ese fundamento estético de las cosas. Cierto que para nosotros ésa es la razón fundamental, pero yo comprendo al mismo tiempo que no tiene validez (y está bien que así sea) para la mayoría. El filósofo, el poeta y el místico tienen la intuición más alta de la creación, y las fronteras que les separan son demasiado sutiles para que no se confundan un poco. ${ }^{7}$

Essas fronteiras estão na raiz de um movimento captado a todo momento em Ocnos. A partir de um dos fragmentos da obra - "La catedral y el río" -, trataremos do referido movimento que, feito transe e em

\footnotetext{
7 "Lamento que não tenha lido Ocnos; não está ruim, mas falharam nas erratas que não estavam nas provas, ainda que sejam erratas visíveis e que não alteram o texto, mas sua ortografia. Para mim é quase um alívio ver essas páginas publicadas; são ou pretendem ser um resgate da minha vida, da vida em geral. Como é natural, espero que o livro caia num poço de silêncio, e sem contradição espero ao mesmo tempo que o livro dure mais do que eu mesmo. [...] Teu comentário sobre o livro já podes supor o quanto me agrada. Não me estranha essa coisa de levá-la à infância que a leitura do livro te dá: em temperamentos semelhantes, como os nossos, ainda que o meio seja diferente, é natural que a reação seja parecida. O que entre nós dois eu não acho que seja tão semelhante assim é o fundamento estético das coisas. Claro que para nós essa é a razão fundamental, mas não compreendo que não tenha validade (e é bom que seja assim) para a maioria. O filósofo, o poeta e o místico têm a intuição mais alta da criação, e as fronteiras que os separam são muito sutis para que não se confundam um pouco.”
} 
trânsito, está dentro daquilo que chamaremos "geografia textual oracular" ou o "complexo lugar não lugar" de Ocnos.

\section{“LA CATEDRAL Y EL RÍO” E O TEXTO ORACULAR EM TRANSE E EM TRÂNSITO DE OCNOS}

O primeiro texto de Ocnos tem o título de "La poesía”, do qual o poeta se serve, na verdade, para falar de música, ou melhor, poesia como música, mais precisamente do som de um piano vizinho que preenchia - todo o tempo verbal desse texto dá notícia de uma experiência indelével, próxima da obsessão - aparentes formas, que estariam vazias pela ausência do som, como se o eco dessa música desenhasse o interior da casa, seus cômodos e também configurasse seu lugar no mundo e os sentidos do poeta. Pelo som daquela música tudo ali estava "cálido y dorado" [quente e dourado], instaurando uma correspondência com o próprio espírito humano, no entender do autor, apreendido como um respiro, um ressoar, um eco, um som. "El nimbo trémulo", "un punto luminoso", "el sueño inconsciente del alma infantil", "resplandor vago", "ala palpitante" e "notas cristalinas y puras de la melodía" são expressões encadeadas de uma partitura que amalgama pintura e composição musical, evidenciando, ao mesmo tempo, o caminho de uma sensação que se desdobra para a percepção da inconsciência, que no texto é dada como o inusitado, e percepções que também correspondem ao ato de lembrar e escrever, sobretudo enquanto se escreve.

A sensaçãoquedeixou uma marca - a poesia - numa memória ancorada ao sabor do transcorrer do tempo que a reinterpreta incessantemente é tal, que seu estranho vislumbre pela audição nos dá a poesia como lucidez. Sua música de naufrágio - o ido e o perdido cuja face se quer recuperar nos comunica, pelas ondas que estão à tona e em movimento, os sargaços de uma mesma e diferente memória, que afunda e torna a emergir sem cessar. A poesia, desse modo, como um cantar de vida e morte em meio à percepção dos sentidos e à construção da linguagem aprendida e embaralhada pela experiência, está assim apresentada nesse portal de Ocnos, como lugar indelimitável porque sua geografia desconhece começo e fim, e seu lugar, à semelhança da carga simbólica com que seus

${ }^{8}$ Respectivamente: "aura trêmula", "um ponto luminoso", "o sonho inconsciente da alma infantil”, "vago resplendor", "asa palpitante", "notas cristalinas e puras da melodia”. 
textos são construídos, revela certo parentesco com as máximas de (re) interpretação individual dos antigos oráculos, próximos aos templos para onde acorriam os de sede pelo incognoscível. Incognoscível, sim, mas que nem por isso não se deixa nomear, pintar, compor, escrever, inscrever, marcar, representar, revelar e significar.

Vejamos, depois dessa abertura que nos proporciona "La poesía”, e pensando na arquitetura textual da obra, o exemplo de um dos textos de Ocnos, "La catedral y el río"; texto que, em nosso entender, além de possuir todos os elementos que vimos tratando, também amplia nossa visão para o fato de que sua leitura expressa releitura, tanto quanto sua linguagem expressa o alcance de uma ficção possível, ao reconhecer pedaços de experiências recolhidas tempos depois de experimentadas, como elos que organizam campos inconciliáveis, sejam eles objetivos, subjetivos ou "terceira margem".

\section{LA CATEDRAL Y EL RÍO}

Ir al atardecer a la catedral, cuando la gran nave armoniosa, honda y resonante, se adormecía tendidos sus brazos en cruz. Entre el altar mayor y el coro, una alfombra de terciopelo rojo y sordo absorbía el rumor de los pasos. Todo estaba sumido en penumbra, aunque la luz, penetrando aún por las vidrieras, dejara suspendida allá en la altura su cálida aureola. Cayendo de la bóveda como una catarata, el gran retablo era sólo una confusión de oros perdidos en la sombra. Y tras de las rejas, desde un lienzo oscuro como un sueño, emergían en alguna capilla blanca formas enérgicas y extáticas.

Comenzaba el órgano a preludiar vagamente, dilatándose luego su melodía hasta llenar las naves de voces poderosas, resonantes con el imperio de las trompetas que han de convocar a las almas en el día del juicio. Mas luego volvía a amansarse, depuesta su fuerza como una espada, y alentaba amoroso, descansando sobre el abismo de su cólera.

Por el coro se adelantaban silenciosamente, atravesando la nave hasta llegar a la escalinata del altar mayor, los oficiantes cubiertos de pesadas dalmáticas, precedidos de los monaguillos, niños de faz murillesca, vestidos de rojo y blanco, que conducían ciriales encendidos. Y tras ellos caminaban los seises, con su traje azul y plata, destocado el sombrerillo de plumas, que al llegar ante el altar colocarían sobre sus cabezas, iniciando entonces unos pasos de baile, entre seguidilla y minué, mientras en sus manos infantiles repicaban ligeras unas castañuelas.

Ir al atardecer junto al río de agua luminosa y tranquila, cuando el sol se iba poniendo entre leves cirros morados que orlaban la línea pura del horizonte. 
Siguiendo con rumbo contrario al agua, pasada ya la blanca fachada hermosamente clásica de la Caridad, unos murallones ocultaban la estación, el humo, el ruido, la fiebre de los hombres. Luego, en soledad de nuevo, el río era tan verde y misterioso como un espejo, copiando el cielo vasto, las acacias en flor, el declive arcilloso de las márgenes.

Unas risas juveniles turbaban al silencio, y allá en la orilla opuesta rasgaba el aire un relámpago seguido de un chapoteo del agua. Desnudos entre los troncos de la orilla, los cuerpos ágiles con un reflejo de bronce verde apenas oscurecido por el vello suave de la pubertad, unos muchachos estaban bañándose.

Se oía el silbido de un tren, el piar de un bando de golondrinas; luego otra vez renacía el silencio. La luz iba dejando vacío el cielo, sin perder éste apenas su color, claro como el de una turquesa. Y el croar irónico de las ranas llegaba a punto, para cortar la exaltación que en el alma levantaban la calma del lugar, la gracia de la juventud y la hermosura de la hora (CERNUDA, 2005, p. 566-567).9

9 "Ir ao entardecer à catedral, quando a grande nave harmoniosa, funda e ressoante, adormecia com seus braços pendurados em cruz. Entre o altar maior e o coro, uma almofada de veludo vermelho e surdo absorvia o rumor dos passos. Tudo estava em penumbra, ainda que a luz, penetrando pelos vitrais, deixasse lá nas alturas sua cálida auréola. Caindo da abóboda como uma catarata, o grande retábulo era apenas uma confusão de ouro perdido na sombra. E atrás das grades, a partir de uma tela escura como um sonho, emergiam em alguma capela branca formas enérgicas e estáticas. Começava o órgão a preludiar vagamente, dilatando-se logo sua melodia até encher as naves de vozes poderosas, ressonantes, com o império das trombetas que convocarão as almas no dia do Juízo. Mas logo voltava a mansidão, depondo sua força como uma espada, e seu alento amoroso, descansava sobre o abismo de sua cólera. Pelo coro se adiantavam silenciosamente, atravessando a nave até chegar à escalinata do altar maior, os sacerdotes cobertos de pesadas túnicas, precedidos pelos coroinhas, garotos de aspecto murilhesco, vestidos de vermelho e branco, que conduziam velas acesas. E, depois deles, caminhavam os meninos do coro, com seu traje azul e prata, portando o pequeno chapéu de plumas, que ao chegar ao altar colocariam sobre suas cabeças, iniciando então uns passos de dança, entre popular e minueto, enquanto em suas mãos infantis repicavam, ligeiras, umas castanholas. / Ir ao entardecer ao rio de água luminosa e tranquila, quando o sol se punha entre leves cirros violetas que ondeavam a linha pura do horizonte. Seguindo rumo contrário à agua, passada já a branca fachada belamente clássica da Caridade, umas muralhas ocultavam a estação, a fumaça, o ruído, a febre dos homens. Logo, novamente em solidão, o rio era tão verde e misterioso como um espelho, copiando o vasto céu, as acácias em flor, o declive argiloso das margens. Uns risos juvenis turvavam o silêncio, e ali na margem oposta rasgava o ar um relâmpago seguido de um mergulho na água. Nus entre os troncos da margem, os corpos ágeis como um reflexo de bronze verde apenas obscurecido pelo velo suave da puberdade, uns garotos estavam banhando-se. Ouvia-se o apito de um trem, o piar de um bando de andorinhas; logo outra vez renascia o silêncio. A luz ia deixando vazio o céu, sem que ele perdesse a cor, claro como o de um azul turquesa. E o coaxar irônico das rãs chegava ao limite, para cortar a exaltação que na alma levantavam a calma do lugar, a graça da juventude e a beleza da hora." 
Na obra de Luis Cernuda encontramos muitos "atardeceres". São tempos crepusculares que assumem variadas formas e tratam, em sua maior parte, de conceituar e pontuar desde a finitude da vida até mesmo o rosto ou a silhueta de um amor perdido. Mas também são lugares e experiências que aprofundam o conhecimento de si e do mundo. Dois desses "atardeceres", além do tratado no texto acima, merecem destaque. O primeiro, presente no livro Las nubes (1937-1940), é o poema intitulado "Atardecer en la catedral" (CERNUDA, 2005, pp. 282-284), no qual esse momento do fim da tarde nos é dado como um ser divino, com poder de revelação; essa hora do dia é a própria figura de um anjo se materializando, enquanto o poeta descreve/pinta a catedral sob essa luz específica que só os entardeceres possuem. Do encontro dessa escrita/pintura da catedral sob a luz angelical e entardecida surge a vigília/prece: o poema. A última estrofe (vv. 58-63), à guisa de arremate, reforça as sensações que na memória são guardadas pelo sentido que prescinde da visão, igualando percepção e mistério:

Aromas, brotes vivos surgen,

Afirmando la vida, tal savia de la tierra

Que irrumpe en milagrosas formas verdes,

Secreto entre los muros de este templo,

El soplo animador de nuestro mundo

Pasa y orea la noche de los hombres

(CERNUDA, 2005, p. 577). ${ }^{10}$

O segundo "atardecer" que destacamos está em Ocnos, num de seus textos/fragmentos igualmente intitulado "Atardecer". Semelhante ao arremate dos últimos versos do citado poema de Las nubes, é todo conduzido pela lembrança olfativa dos aromas das flores nas noites de verão. Enquanto descreve brevemente os terraços das casas numa correspondência à altura do que se vê/cheira/sente, todos os sentidos convergem para descrever a forma de um desejo "que emana de un cuerpo joven, próximo en la tiniebla estival” (CERNUDA, 2005, p. 361). ${ }^{\text {" O poema }}$ de Las nubes e o fragmento "Atardecer" estão aqui citados não só para reforçar esse lugar/elemento/cor/símbolo presente na obra cernudiana, como já o dissemos, mas também para evidenciar o ponto em comum

\footnotetext{
10 "Aromas, brotos vivos surgem, /Afirmando a vida, como seiva da terra /Que irrompe em milagrosas formas verdes, /Segredo entre os muros deste templo, /O sopro animador do nosso mundo / Passa e perfuma a noite dos homens."

11 “[...] que emana de um corpo jovem, como a densidade noturna de verão."
} 
de construção/arquitetura de escrever/descrever/pintar que existe entre ambos e permeia o principal texto de nossa análise, "La catedral y el río". Trata-se de um elemento, dito ecfrástico, mas teoricamente construído a partir da famosa expressão horaciana Ut pictura poesis [a poesia tal como a pintura].

Se o poema de Las nubes nos dá a medida desse recurso utilizado e tão bem desenvolvido por Cernuda - apenas para ficarmos na metáfora outonal do entardecer -, os textos de Ocnos nos revelam o berço da maturidade estética do poeta, consolidada no período em que vive em Londres, geografia de nascimento do livro que tem o pensamento na Espanha, claro, mas de forma fractal e contaminada pelos fogs londrinos. As duas geografias são confundidas: não há memória segura no desterro, e o exílio dado como tempo presente obriga-o a edificar um lugar, por isso mesmo, indefinido. E a indefinição está longe de ser um dado de menor importância em Ocnos, o que a torna - a obra - ainda mais enigmática e generosa. Enigmática porque, ao convocar em sua prosa ensaística/ poética elementos memorialísticos, fragmentos de crônicas, pedaços de contos, versos deslocados, descrições paisagísticas, geográficas e arquiteturais dentro de um pensamento muito semelhante ao discurso filosófico que toma a arte como objeto de especulação e construção de conhecimento, ela nos obriga a decifrar e estabelecer pontes de referência; já a generosidade é pela ampla leitura que nos proporciona: Ocnos se entrega no abandono pelo leitor das ferramentas habituais de análise textual; Ocnos pede interrogações e volteios sem teratologia, além de uma espécie de diálogo que nos leva à boa perdição, que é o trançar dos juncos destinados ao apetite de um inocente asno.

Mencionar a expressão horaciana não é afirmar a filiação direta de Luis Cernuda à arte poética latina, mas às transformações desta ao longo do tempo, sobretudo pelos tratados e preceptivas dos séculos XVI e XVII e, mais diretamente, à leitura que o poeta faz dos alemães, leia-se Goethe, e seus discursos sobre a arte. No primeiro caso, e apenas como referência para aumentar o diálogo e ver como são difíceis de determinar as fronteiras pelas quais se disseminam os pensamentos sobre o fazer artístico, nesse caso o pictórico/poético, citamos uma resumida argumentação de um tratado seiscentista (MUHANA, 2002, pp. 78-8o) e sua pertinência como um possível olhar, algo ruinoso, a bem dizer, de fratria estética: 
do corpo e os afetos da alma, ou, como disse Luciano, retrata a formosura do corpo e a virtude do ânimo. [...] A pintura faz-se para o sentido, e a poesia para o espírito. Dar nome a cada coisa ajustado à sua natureza é mais dificultoso que pintá-la. Podem ser ignorantes os pintores, e pintar bem sabendo a arte, mas não poderá o néscio dar nomes, que representem o natural das coisas. A poesia faz naturalmente uma coisa parecer sempre a mesma: a pintura sempre tem na mesma coisa diversidade. Timantes na figura de Ifigênia não pôde expressar a muita tristeza de Agamêmnon; e os poetas, que escreveram tragédias na mesma matéria fundadas, pintaram tudo ao natural, sem encobrirem pessoa alguma; por virtude da narração, obraram o que não podia a sutileza e valentia das cores.

Por maior que seja a pertinência com a criação cernudiana, sua fonte do que podemos chamar de filosofia da arte são os românticos alemães, sobretudo as considerações que Cernuda empresta de Goethe, tanto na própria citação de abertura de Ocnos quanto nos escritos de arte do autor alemão. Como podemos ler em "La catedral y el río", a imaginação que o poeta emprega na descrição da catedral pelos seus símbolos mais fundamentais - a catedral, com seus braços em cruz, vai adormecendo, acompanhando o entardecer - , revela a destreza de um olhar treinado, de quem já muito observou o objeto que descreve, e recuperá-lo implica o conhecimento de pelo menos dois tipos de materiais: os conceitos arquitetônicos e a palavra poética, sobretudo quando essa reedificação pela palavra assume uma gama imensa de propósitos, desde a reedificação de si mesmo até o exercício de expandir as interrogações implícitas no texto, ao descrever os movimentos e as relações que o tempo e as gentes que frequentam a catedral com ela mantêm. O exercício imaginativo convoca os sentidos do poeta sem o menor julgamento religioso, antes, demonstra o poder de recriar - ou trançar, para ficarmos na metáfora central de Ocnos - o testemunho de uma beleza que, ainda que se trate de um edifício, está em movimento, seja pelo olhar de quem a contempla, seja pelo tempo, que soberana e invisivelmente, não fosse o olhar do poeta, devora a imponente catedral. Como afirma Goethe (2008, p. 251) em "A imaginação":

A imaginação parece, na verdade, não possuir leis, talvez seja como um sonho em estado de vigília, que oscila incondicionalmente de um lado para o outro. Mas para possuí-la é preciso regrá-la de diversas maneiras, mediante o sentimento, mediante incentivos éticos, mediante necessidades do agir e da maneira a mais feliz mediante o gosto, por meio do qual a razão se apodera de cada matéria e de todos os elementos. 
A escrita de Luis Cernuda, como podemos constatar em "La catedral y el río”, demonstra uma condição de vigília poética ao erigir sua catedral com sons que se ampliam nos tubos de um sonoro e potente órgão, e se juntam à percussão de castanholas com agilidade e frescura infantis, trançando origens e sons diversos que estão reunidos numa ciranda um tanto dervixe, que retoma as primeiras qualidades dessa música que habita a catedral "armoniosa, honda y resonante" [harmoniosa, funda e ressonante] (CERNUDA, 2005, p. 566) como características principais do que está em trânsito, sejam seus frequentadores, seja a respiração da música que passa a ser a própria respiração da catedral.

Outro ponto de interesse do poeta sempre foi a beleza e o modo como, ao referir-se a ela, é possível obter uma parte dos seus dons e dotes, sem referência a ornatos ou aparências vazias de casca, mas a beleza profunda que molda um caráter, dá aprumo e sustenta com alegria evigor a celebração de pequenos e raros oásis em meio a uma vida/geografia inóspita em sua maior parte. Essa procura pela beleza e toda sua obra, como aqui em Ocnos, cumpre o ideal fundador de uma religião que o poeta nunca teve. Essa catedral cernudiana é o ideal da sua ética-estética, cantando, resplandecendo sob o entardecer e sendo habitada por signos amados por Cernuda: a música, o sol, a pintura, a escultura, o alento amoroso capaz de fazer descansar a cólera nos abismos, uma certa fraternidade civilizatória e a presença de crianças consagradas a uma infância que, pelo encanto e pela voz, biograficamente o poeta busca restituir à vivenciada com repressão e silêncio. Nesse sentido, convém voltar mais uma vez a Goethe (2008, p. 195) para apontar um diálogo que certamente amplia nosso olhar para a composição de Ocnos:

[...] A arte tem uma origem ideal, pode-se dizer que ela nasceu da religião e com a religião. Nos tempos mais antigos, a arte sempre serviu à religião, ao configurar certas representações rigorosas, nebulosas, estranhas ou violentas. [...] Uma lenda graciosa afirma que a sombra de um amante forneceu a ocasião para a invenção da arte de desenhar. Somente a inclinação limita o sentimento quando, ao contrário, a religião o aumenta. [...] A arte autêntica possui uma origem ideal e uma direção ideal, ela tem um fundamento real, mas não é realista. [...] A beleza natural está submetida às leis da necessidade, a beleza artística às leis do espírito humano sumamente desenvolvido, aquela nos aparece, por assim dizer, presa, esta, por assim dizer, livre.

A construção de "La catedral y el río" obedece a uma descrição, sem dúvida, mas é uma descrição estranhamente trançada entre as referências concretas da arquitetura com preceitos de uma conduta espiritual, 
dentro de um tempo-espaço - o entardecer - desenhando o pensamento simbólico de um lugar onde toma assento o inefável. Tratada assim, como epifenômeno, seu objetivo mais parece um construir de ocultas interrogações, pelo que vai colhendo e espalhando, como se atirasse pistas para inquirir os pronomes queaí se ocultam, transformando solilóquios em diálogos. A presença desse recurso já podemos constatar num poema que toma outra arquitetura religiosa como reconstrução de tempos e espaços: no poema "El ruiseñor sobre la piedra" [O rouxinol sobre a pedra], de Las nubes, Cernuda descreve e rememora El Escorial (Monastério em San Lorenzo, Madri) como uma memória trazida por um pássaro e seu canto, pousado sobre uma pedra que é a ruína/oráculo, não do Monastério, mas da sua lembrança achada/perdida. De semelhante maneira, porém com mais indefinição geográfica, recupera essa catedral de "La catedral y el río” pelo entardecer e todo seu amplo campo simbólico, ainda que pareça destinado a marcar o indemarcável, pois os "atardeceres" são movimentos, a representação própria da vida. Esses movimentos que não têm destino, ou destinados ao nada, pelo menos ao nada do que se espera, colocam os "atardeceres" cernudianos como a expressão de uma forma que confessamente pode ser entendida como exorcismo, em se tratando de uma catedral que edifica nossa conduta aparentemente contraposta a um rio que nos batiza. A noção de solilóquio transformado em diálogo como uma forma de exorcismo talvez seja melhor compreendida pela chave pagã de Cernuda e a concepção de daimon que carrega consigo.

José Bergamín (1895-1983), exilado como Cernuda, publicou, em 1959, um conjunto de ensaios que aborda oito escritores fundamentais para a literatura, entre eles, Sêneca, do qual extraímos um breve trecho para, a partir dessa noção de exorcismo, poder alcançar uma das noções da escritura de Ocnos, como um trançar de constatação lúcida e trágica da qual o poeta se defende com seu solilóquio convertido em diálogo:

Vuelvo, decía como ejemplo, a la ficción mítica infernal de la tragedia antigua, griega y latina. Ahora a Eurípedes y Séneca. Y con ellos, al héroe que vuelve del Infierno. Y que vuelve vencedor de él, o creyendo haberlo vencido. Ya sabemos lo que pasa. Lo ha vencido por fuera, como si dijéramos. Ha logrado sacar a la luz del día, a la claridad solar, su más terrible monstruo oscuro, tenebroso, haciéndole perecer de ese modo, por la luz misma. Nosotros sabemos - así lo afirma una médica terapéutica, a veces eficaz, como otras contraproducente, llamada psicoanálisis impropiamente por su genial inventor -, sabemos que sacar al día claro de nuestra razón - suponiendo que nuestra razón sea tan clara, lo que es suponer mucho más de lo que se atrevió a suponer tan audazmente Descartes -, que sacando, decimos, a la luz del día estos 
oscuros y tenebrosos monstruos diabólicos, pueden perecer y librarnos de su desagradable presencia invisible y devoradora. Sabemos combatir a muchos de estos monstruos devoradores humanos. Sabemos que han cambiado las técnicas del exorcismo, y que hoy podemos exorcizar monstruos diabólicos, a veces, con mejores resultados prácticos: lo que no es poco. El hombre de acción que era el Heracles o Hércules del trágico mito es azañero exorcista o matador de monstruos, benéfico libertador popular de ellos. Su conducta es heroica y semidivina. Como prueba final de su poder y fuerza, vuelve del Infierno, aparentemente vencedor de su pútrido laberinto entrañable, generados de espantos y maldades. Ya sabemos lo que le pasa. Los dioses, envidiosos de su poder, o sencillamente caprichosos e injustos, esto es, muy verdaderamente divinos, le tienden una trampa. Van a hacerle entrar en otro Infierno que aquél de donde vuelve. [...] Hasta ahora no ha vencido al Infierno; o ha vencido al Infierno ilusorio, diríamos, realmente ilusorio, o irreal: porque más allá de la muerte. Pero este otro Infierno atroz, que liga con su sangre a su destino; este Infierno actual y actuante en él, más acá de la muerte, le ha vencido a él: y pide entonces, paz a los cielos; pide volver de nuevo al otro Infierno, al que está más allá del tiempo y de la muerte; y aún más allá del bien y del mal humanos; a ese otro Infierno perdido, que su recuerdo, en el presente, le finge como casi un Paraíso (BERGAMÍN, 2008, pp. 37-38). ${ }^{12}$

12 "Volto, dizia como exemplo, à ficção mítica infernal da tragédia antiga, grega e latina. Agora a Eurípedes e Sêneca. E, com eles, ao herói que volta do Inferno. E que volta vencedor dele, ou acreditando tê-lo vencido. Já sabemos o que acontece. Venceu o Inferno por fora, a bem dizer. Conseguiu mostrar à luz do dia, à claridade solar, seu mais terrível monstro escuro, tenebroso, fazendo-o perecer desse modo, pela luz mesma. Nós sabemos, tal como afirma uma terapeuta, às vezes eficaz, outras contraproducente, chamada indevidamente de psicanálise pelo seu genial inventor, sabemos que colocar nossa razão à luz do dia, supondo que nossa razão seja tão clara, o que pode supor também muito mais do que se atreveu supor Descartes, que, colocando, dizíamos, à luz do dia esses escuros e tenebrosos monstros diabólicos, podem perecer e nos livrar da sua desagradável presença invisível e devoradora. Sabemos combater a muitos desses monstros devoradores humanos. Sabemos que mudaram as técnicas de exorcismo e que hoje podemos exorcizar monstros diabólicos. Às vezes, com melhores resultados práticos, o que não é pouco. O homem de ação que era o Hércules (ou Héracles) do mito trágico é habilidoso exorcista ou matador de monstros, benéfico libertador popular deles. Sua conduta é heroica e semidivina. Como prova final do seu poder e força, volta do Inferno, aparentemente vencedor do seu pútrido labirinto entranhável, cheio de espantos e maldades. Já sabemos o que acontece. Os deuses, invejosos do seu poder, ou simplesmente caprichosos e injustos, isto é, muito verdadeiramente divinos, o colocam numa armadilha. Farão com que entre em outro Inferno, diferente daquele de onde voltou. [...] Até agora não venceu esse Inferno outro; ou venceu o Inferno ilusório, digamos, realmente ilusório, ou irreal, porque está mais além da morte. Este outro Inferno é atroz e liga o destino ao sangue; esse Inferno atual e atuante nele, próximo à morte que conhecemos, na verdade venceu o herói. Então, este pede paz aos céus; pede para voltar outra vez ao primeiro Inferno, aquele que está para além do tempo e da morte; e ainda mais além do bem e do mal humanos; a esse outro Inferno perdido, sua lembrança, no presente, finge-se ao herói como se fosse um Paraíso." 
Para Cernuda (2005, p. 310) a conjugação simultânea de duas histórias, como já o dissemos no início, a História e a sua história, pode ser resumida em dois versos do poema que escreve em Las nubes, "Un español habla de su tierra" (vv. 07-08): "La vida con la historia /Tan dulces al recuerdo". ${ }^{3}$ É não apenas o paraíso fingido a que Bergamín faz referência, como também o lugar que a consciência do poeta exilado Luis Cernuda alcança; um lugar que é o limite da lucidez e a contenção da loucura; o fabrico dos paraísos artificiais baudelairianos, a geografia dos templos - nesse caso das catedrais e suas falas incompreensíveis, porque não primam pela razão que pode aniquilar o homem, mas são erigidas para dar consolo e beleza e aconchego aos seus entardeceres.

A construção da catedral de "La catedral y el río" está numa margem; na outra está propriamente o outro "atardecer", com suas cores e sons igualmente sagrados, fazendo a transição dos ligeiros movimentos infantis das castanholas para a juventude banhando-se nas águas de uma mesma vida, mas, em outra extensão, numa sequência clara de despedida e encontro. A construção da catedral encontra a circulação do rio onde correm as vozes da divindade, da juventude.

Dizer que voltar ao passado por não ver um futuro seria uma atitude ingênua para alguém que, como Cernuda, é movido por ceticismo e beleza; seu olhar para o passado é para interpelar a si próprio como uma possibilidade de sonhar sem enfraquecer o desejo, única certeza que alimenta, como conclui em "Cuatro poemas a una sombra", de Vivir sin estar viviendo. Ocnos recebeu do seu autor a excitação semelhante da primeira publicação do seu primeiro livro de poemas, Perfil del aire (1924-1927), depois renomeado como Primeras poesías, e foi como se estivesse de posse de uma nova ferramenta para lascar a mesma e dura pedra do real; procurou tornar cada vez mais cortante o seu desejo de poeta para adensar e ampliar o fazer literário. Ao poeta, ao crítico e ao tradutor incorpora-se, com Ocnos, o narrador de oráculos e fragmentos que, à maneira de Heráclito, não revelam, mas significam.

Pode causar estranheza falar de um texto de linguagem poética que reúne elementos de écfrase, poesia, memória, crônica etc. e emparelhá-lo com a arte divinatória do passado. Mas em Cernuda, pelo perdido incomensurável, é uma expressão comum e pertinente. Ocnos forma-se por esses oráculos, pelo que escapa sem termo: um campo de memórias

${ }^{13}$ Respectivamente: "Um espanhol fala da sua terra" e "A vida com a história /Tão doce à lembrança”. 
em pegadas, “dejos” por decifrar e, também, um exercício psicanalítico. Não que Cernuda seja um escritor freudiano, mas convoca muitos recursos da psicanálise para enfrentar os enganos e toda uma nação de esquecimentos/lembranças que rebrotam às margens, muitas vezes ao centro, do caminho que percorre.

É famoso o ensaio sobre Leonardo Da Vinci, no qual Sigmund Freud (2006) se debruça sobre um traço do caráter do renascentista - a saber, o hábito de deixar inacabadas tantas obras -, relacionando-o a uma lembrança da infância do multifacetado artista da Renascença. Discorrendo acerca da sublimação do amor em Da Vinci, escreve:

[...] convertera sua paixão em sede de conhecimento; entregava-se, então, à investigação com a persistência, constância e penetração que derivam da paixão e, ao atingir o auge do seu trabalho intelectual, isto é, a aquisição do conhecimento, permitia que o afeto há muito tempo reprimido viesse à tona e transbordasse livremente, como se deixa correr a água represada de um rio (FREUD, 2006, p. 83).

E, mais adiante: "O adiamento do amor até o seu pleno conhecimento constitui um processo artificial que se transforma em uma substituição” (FREUD, 2006, p. 84).

E, ainda:

Um homem que começou a vislumbrar a grandeza do universo com todas as suas complexidades e suas leis, esquece facilmente sua própria insignificância. Perdido de admiração e cheio de verdadeira humildade, facilmente esquece ser, ele próprio, uma parte dessas forças ativas e que, de acordo com a medida da sua própria força, terá um caminho aberto diante de si para tentar alterar uma pequena parcela do curso preestabelecido para o mundo - um mundo em que as menores coisas são tão importantes e extraordinárias quanto o são as coisas grandiosas (FREUD, 2006, p. 84).

Trazemos essas frestas da teoria freudiana sobre uma característica do gênio florentino para tratar do que em Ocnos também se vê contaminado: o abandono. Segundo Freud, o que faz Leonardo Da Vinci abandonar muitas de suas obras, ou seja, deixá-las incompletas é um complexo infantil que o psicanalista encontra no pintor da Gioconda como uma substituição do prazer infantil pela imortalidade do lúdico, do jogo, entre outras questões de sublimação sexual também. No caso cernudiano, a composição de Ocnos, a nosso ver, também participa dessa condição de inacabados e/ou abandonados, mas diferentemente do complexo que Freud aponta em Da Vinci, a descoberta de um novo território textual 
que Cernuda experimenta é adubada com essa inconclusão, com essa incompletude com aparência de abandono. Ocnos, definitivamente, insere-se, pela sua instabilidade, como uma ferramenta para abarcar o inapreensível, a rebeldia das palavras e da linguagem, que se disfarça em harmonia pela brevidade de seus fragmentos e pedaços que, na verdade, mais se parecem a rupturas ou cisões.

Ao abordar a obra de Valéry para tratar do que chama de "cisão entre a curiosidade intelectual na prosa e o atavismo mitopoético no verso", Michael Hamburger (2007, p. 135) cita uma declaração de Juan Ramón Jiménez (JRJ), na qual o poeta espanhol afirma que "quem quer que progrida numa disciplina (poesia, por exemplo, religião, arte ou ciência etc.) inevitavelmente progredirá em todas as outras, mesmo que não as considere individualmente suas”. Claro que essa declaração está dentro de um contexto específico que é, por um lado, historicamente democrático liberal e, por outro, expõe uma faceta da sua formação neoplatônica de desenvolvimento intelectual e espiritual. Mas ambas as considerações de Hamburger nos interessam na medida em que invocam duas expressões que são caras à obra cernudiana: "atavismo mitopoético" e "disciplina". Convém mencionar ainda que Juan Ramón Jiménez (2006) também criou seu Ocnos, Platero y yo, obra à qual foi acrescentando episódios narrativos/poéticos ao longo de anos, e que até hoje, porvestir um disfarce/ carapaça de fábula, tem sido lida como texto filosófico, etimológico, memória e mesmo como infanto-juvenil. De todo modo, e sobre "atavismo mitopoético" e "disciplina”, poucos termos como esses respondem tão bem pela vitalidade com que Cernuda se portou frente à sua obra de uma forma em geral, construindo o que podemos chamar de "realienação", sobretudo em Ocnos, como uma cessão a este Outro perdido, feito o espelho do "Das Umheiliche" [O estranho] freudiano, cujo fiapo de voz reverbera em momentos súbitos e decisivos de uma memória que guarda e perde os saberes da vida e do mundo com um vulto de fera insone.

Isso é o que cala e se faz ouvir na catedral e no rio. O primeiro como construção trançada e destinada à circulação das águas do segundo. O não gênero de Ocnos é mais uma de suas qualidades. Seu gênero silenciado ou um gênero do silêncio deságua num discurso a posteriori. Se o inclassificável gera distanciamento e incompreensão, Cernuda sorri, porque se sente bem acompanhado. Como declara em Historial de un libro, parafraseando Heráclito: "Caráter es destino" [Caráter é destino] (CERNUDA, 2002, p. 661). 


\section{REFERENCIAS}

APULEIO, Lúcio. O asno de ouro. Trad. Ruth Guimarães. Cultrix: São Paulo, 1985.

BERGAMÍN, José. Fronteras infernales de la poesía. Madrid: Huerga y Fierro Editores, 2008.

CERNUDA, Luis. Epistolario 1924-1963. Edición de James Valender. Madrid: Residencia de Estudiantes, 2003.

CERNUDA, Luis. Poesía completa. Madrid: Siruela, 2005.

CERNUDA, Luis. Poetas en la España leal. In: Prosa II. Madrid: Siruela, 2002[1937], pp. 123-126.

CERNUDA, Luis. Palabras antes de una lectura. In: Prosa I. Madrid: Siruela, 2002[1935], pp. 6o1-6o6.

FREUD, Sigmund. Cinco lições de psicanálise, Leonardo da Vinci e outros trabalhos. In: Obras completas. V. XI. Rio de Janeiro: Imago, 2006[1910], pp. 73-141.

GOETHE, Johann Wolfgang. Escritos sobre arte. Trad. Marco Aurélio Werle. São Paulo: Humanitas / Imprensa Oficial, 2008.

HAMBURGER, Michael. A verdade da poesia. Tensões na poesia modernista desde Baudelaire. São Paulo: Cosac e Naify, 2007.

JIMÉNEZ, Juan Ramón. Platero y yo. Madrid: Cátedra, 2006.

MUHANA, Adma. Poesia e pintura ou pintura e poesia. Tratado seiscentista de Manuel Pires de Almeida. Trad. do Latim de João Ângelo Oliva Neto. São Paulo: Edusp, 2002, pp. 78-8o.

ROSA, João Guimarães. Grande sertão: veredas. Rio de Janeiro: Nova Fronteira, 2001. 